\title{
What Family Businesses Should be Doing Now
}

\author{
Kimberly Eddleston (Northeastern University)
}

KEYWORDS: Management, Finance, Family Business, crisis management, \#familybusiness.

As family business leaders are forced to deal with COVID-19, Winston Churchill's advice comes to mind: "Never let a good crisis go to waste." This suggests that as family firms temporarily close down or adjust their business models to the pandemic, they should also be taking this time to improve multiple facets of their businesses.

Threats to survival push family businesses to reassess their strengths and weaknesses and to scan the environment for opportunities and challenges coming their way. The threats also tend to bring the family together, as they work to sustain the firm's viability for future generations. In addition, as family businesses try to navigate the uncertainty and risk associated with the pandemic, they can reassess whether their current strategies and human capital will still serve them in the future. In short, it is often easier to introduce changes in a family business when it is facing threats to survival or in the process of implementing another change. Thus, this crisis likely presents an opportunity for family businesses to improve several facets of their business and to put in place practices that they have long had on their "to do" lists.

With many of the world's leading family business scholars on the board of FamilyBusiness.org, we therefore offer the following pieces of advice for family businesses dealing with the current pandemic. These are things family business leaders should consider doing now to help them deal with the current crisis and prepare them for when they open for business again, whether that's a full or gradual process. Many of our board members are working tirelessly to help support their family business clients; we hope these tips also help your business to weather the storm and re-emerge stronger and healthier when the sun shines again.

\section{Lean on History}

"Look for a reference point to be able to understand the severity of the current crisis. The reference point could be the 2009-2010 financial crisis, 9/11, a revolution in another country, the great depression, etc. In other words, reference points stemming from other crises can put the current crisis into perspective. Moreover, business owners can learn what businesses did in other crises to survive and rebound." -- Peter Jaskiewicz, Ph.D., University of Ottawa

"It is important to remind employees of the resilience of the family business throughout history. Make your history a strategic resource by bringing together the family to reflect among generations on the past challenges the business managed to overcome and draw lessons that can help the family think about crises as opportunities for change. It is a unique sharing opportunity for the senior generation and a unique learning and entrepreneurial opportunity for the next generation." -- Rania Labaki, Ph.D., EDHEC Family Business Center

\section{Innovate with Less}

"Find creative ways to continue serving customers. This includes both new products (e.g., beverage producers that now produce disinfection solutions; fashion providers making masks; companies in the plastics business producing separating "walls" for supermarkets, etc.) and new services (e.g., drivethroughs; take-home services; selling B2C instead of only B2B, etc.). For instance, because all hotels and restaurants in our region have been closed, a local family firm vegetable supplier opened up its services to private customers. They pre-package boxes of vegetables that customers can pick up at their farm." -- Nadine Kammerlander, Ph.D., WHU Otto Beisheim School of Business

"Push digitalization efforts (keep any projects related to digitalization running) and invest in remote work. Many family firms are radically transforming their organizations - something they did not have time to do before the crisis, and won't have time to do after. These
Copyright ( $) 2020$ The Authors. Entrepreneur \& Innovation Exchange is published at EIX.org. This is an open access article under the terms of the Creative Commons Attribution-NoDerivs License, which permits use and distribution in any medium, provided the original work is properly cited and no modifications or adaptations are made. View EIX.org Authorship Terms at https://eix.org/terms
FamilyBusiness 
family firms should be well prepared for what comes after the crisis. Innovative family firms are also getting their employees involved by offering creativity contests for new products and business ideas." -- Claudia Astrachan Binz, Ph.D., Lucerne University of Applied Sciences and Arts

"Family firms are known for innovating with less - just see my other article (https://familybusiness.org/content/How-Family-FirmsCan-Innovate-With-Less) on this website. This means cutting all unnecessary costs and delaying any nonurgent investments. Family firms also need to make sure that they are aware of and using the policy initiatives that governments from around the world are putting in place to sustain family firms. It is also important that family firm leaders are prepared for this crisis to last longer than we believe, and without panicking, they should constantly adapt as the pandemic evolves." -- Alfredo De Massis, Ph.D., Free University of Bozen-Bolzano and Director of its Centre for Family Business Management

"Family business owners need to radically adjust their business model to survive the current crisis. In many cases, this means cutting costs strongly and rapidly and, to some extent, cutting non-essential investments. If you are a brick-and-mortar store and your government has shut down all brick-and-mortar stores, for instance, you currently do not have a business model." -- Peter Jaskiewicz, Ph.D., University of Ottawa

\section{Put People First}

"Show that you are working to protect your workforce by creating barriers and practices that support social distancing such as (a) physically separating the workforce by using acrylic glass screens; (b) forming $A$, $B, C$ teams that function completely independently (and could be isolated / exchanged in case of infection); and (c) allowing time for cleaning in-between shift changes. Practices that increase hygiene and personal safety should also be implemented (i.e. providing face masks and protective gear, sanitizers and disinfectants). Additionally, it is important to offer generous sick leave policies and to fully support employees working from home by giving them the technology and support they need. This also means offering additional accommodations for those working remotely with children at home." -- Claudia Astrachan Binz, Ph.D., Lucerne University of Applied Sciences and Arts
"Embrace a real long-term perspective - which is typical of family firms - and cut any family-centered expenditures that are not in the long-term interest of the business. This is the time to prioritize the familycentered noneconomic goals that characterize family firms, making their family and employees feel that they are taking care of their health before any business interests. They should ensure the well-being of their people and also of external stakeholders like customers, suppliers." -- Alfredo De Massis, Ph.D., Free University of Bozen-Bolzano and Director of its Centre for Family Business Management

"Among the best practices, family businesses should start an online platform that provides psychological support for their employees to help them deal with the anxiety associated with the crisis and to better manage their work-life balance as they work from home. They can also offer online meditation and yoga subscription classes to their employees to make sure they are staying physically and cognitively fit. These efforts show employees that they are appreciated and supported. A way to keep employees engaged is to bring them together around a philanthropic cause for their community during these difficult times." -- Rania Labaki, Ph.D., EDHEC Family Business Center

"This is a unique opportunity for next generation family members to start taking over the family business. Lockdowns and the higher health risks of older family members offer a chance for next gen members to take on leadership roles for which they could be better equipped considering the technological skills needed right now (e.g., online meetings, direct contacts with overseas suppliers). This is a great time to start this discussion and plan "your own retirement" and the succession plan!" -- Andrea Calabrò, Ph.D., IPAG Entrepreneurship \& Family Business Center CoDirector, and STEP Project Director

\section{Enhance Communication}

"The obvious changes involve lots of communication to ensure that cash needs are met (gaining cash, reducing cash expenses, negotiating with vendors and other creditors, etc.), the level of health and safety procedures are increased, expenses are managed, and government relief programs are pursued. The not so obvious: encourage action with the attitude that we can adjust and fix mistakes later. It is also important to increase communication with suppliers and customers and offer help where you can, thus building bonds that will be 
needed for future crises and for emerging from this one." -- Joseph Astrachan, Ph.D., Cornell University Smith Family Business Scholar

"This is a great time to strengthen communication and talk about governance. A number of our next gens met recently to talk about how they are using this time as an invitation to discuss their vision for the future and steps they can take to build cohesion and governance." -- Carol Wittmeyer, Ph.D., St. Bonaventure University \& Cornell University Smith Family Business Scholar

"It is important to increase your level of external communication and to also adjust what you communicate. Specifically, family businesses should continue communicating with their clients and other external stakeholders (suppliers, banks...) by providing timely information on key decisions and highlighting the connection of these decisions with their identity and values. This communication can also include the philanthropic actions that they are engaging in to support the communities in these times of crisis. This helps maintain the relationship with the stakeholders while waiting for better days. Depending on the industry of the family business, they can also offer free consultations or services to temporarily support their clients." -- Rania Labaki, Ph.D., EDHEC Family Business Center

"Make sure that you stay in contact with your current and potential future customers. A gym in the region put some of its classes online for free. While current revenues and profits are substantially reduced, this activity increases brand awareness and promises to attract new customers once they are reopened." -- Nadine Kammerlander, Ph.D., WHU Otto Beisheim School of Business

"The sharing of information should be frequent and transparent -- for example, weekly calls with top clients and suppliers, and with the top management team. Set up a Twitter account to follow important (government) information; keep informed by reading both news and medical reports, as well as industry-related information. Connect with companies within and outside of your industry to share experiences and best practices, but also to help each other with purchasing masks and other protective infrastructure (build new networks that may outlast the crisis)." -- Claudia Astrachan Binz, Ph.D., Lucerne University of Applied Sciences and Arts

\section{Show Leadership}

"Now is a great time for family businesses to showcase the good they're doing in their communities. A local family-owned restaurant gave away 1000 pizzas in a very well set-up, social-distancing conscious drive to families with food insecurity in our community. They posted and shared on social media and benefitted from both word-of-mouth and engagement with posts." -- Whitney Peake, Ph.D., Western Kentucky University

"Authentic leaders are key in navigating a crisis. At the same time, they should remember they are not invincible human beings in such stressful times. Leaders must take care of themselves to avoid burn-out and learn how to delegate and ask for help, especially from the younger generation. Lastly, they need to build on their emotional intelligence to help spread positive emotions such as empathy through altruistic behavior and genuine care about their stakeholders." -- Rania Labaki, Ph.D., EDHEC Family Business Center

"Do not forget that the choices you'll make today will be ones for which you'll be remembered tomorrow. Be wise and consider all consequences of your actions and decisions especially in these dark days." -- Andrea Calabrò, Ph.D., IPAG Entrepreneurship \& Family Business Center Co-Director and STEP Project Director

"Family business leaders need to stay on top and think ahead. A Corona task force should be formed that meets daily (for example, 12 people to decide upon and track measures) to develop various scenarios for different divisions, far into 2021. The task force should also increase focus and capacity in areas that are not affected by the crisis, to mitigate losses in those areas that are affected. In addition to the business, it is important to take this time to assess family member' wants and needs and to update family business owners' wills!" -- Claudia Astrachan Binz, Ph.D., Lucerne University of Applied Sciences and Arts

"During these times, we have all been thinking about the simple things in life for which we are grateful that we have taken for granted. In family business, we are seeing families and their family-like employees doing their best to help family businesses survive, thrive and even reinvent themselves (such as the many cases of firms who are converting alcohol to sanitizer production lines). So now is a wonderful time to think about who deserves gratitude in our lives, why they deserve it and 
how we might express gratitude." -- Carol Wittmeyer, Ph.D., St. Bonaventure University \& Cornell University Smith Family Business Scholar 